Vol. 04, No. 01 : Hal. $1-8$

Februari 2019

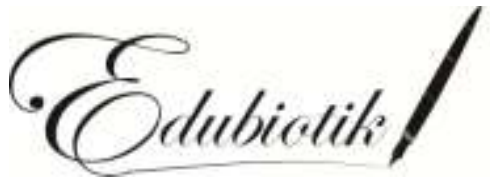

\title{
STUDENTS WORKSHEET BASED ON ANTI CORRUPTION AND HIGHER ORDER THINKING SKILLS (SWACHOTS): MENGEMBANGKAN PEMBELAJARAN LINGKUNGAN ABAD 21
}

\author{
IImi Zajuli Ichsan ${ }^{1}$, Enin Iriani ${ }^{2}$, Farah Muthi Hermawati ${ }^{3}$, Aryani Kadarwati Dewi ${ }^{4}$ \\ ${ }^{1}$ Program Magister Pendidikan Biologi, Fakultas MIPA, Universitas Negeri Jakarta \\ ${ }^{2}$ SD Negeri Jatimulya 02, Tambun Selatan, Bekasi, Jawa Barat \\ ${ }^{3}$ Pendidikan Fisika, Fakultas MIPA, Universitas Negeri Jakarta \\ ${ }^{4}$ SMP Negeri 1 Tambun selatan, Bekasi, Jawa Barat \\ e-mail:ilmi.zajuli@outlook.co.id
}

\begin{abstract}
ABSTRAK
Topik pencemaran sungai merupakan topik pembelajaran yang membutuhkan Keterampilan Berpikir Tingkat Tinggi. Masalah lingkungan juga dipadukan dengan masalah lain, salah satunya, yaitu kasus korupsi dalam isu lingkungan juga menjadi perhatian khusus, sehingga perlu menanamkan nilai-nilai anti korupsi. Tujuan dari penelitian ini untuk mengembangkan Lembar Kerja Siswa berdasarkan Anti Korupsi dan Keterampilan Berpikir Tingkat Tinggi dalam pembelajaran lingkungan. Metode penelitian yang digunakan, yaitu Penelitian dan pengembangan berdasarkan Borg \& Gall (2003). Penelitian ini dilakukan pada 12-18 Oktober 2018 di Sekolah Dasar 2 Jatimulya dan SMP 1 Tambun Selatan, Bekasi. Hasil penelitian menunjukkan bahwa Lembar Kerja Siswa yang dikembangkan valid dan cocok untuk pembelajaran lingkungan untuk siswa SD dan SMP dengan skor rata-rata 3,47. Hal ini karena penyajian Lembar Kerja Siswa sederhana tetapi penuh dengan nilai-nilai Keterampilan Berpikir Tingkat Tinggi dan anti korupsi. Kesimpulanbahwa lembar kerja yang dikembangkan valid dan cocok untuk digunakan dalam pembelajaran lingkungan.
\end{abstract}

Kata kunci:Anti korupsi, HOTS, lembar kerja siswa

\section{ABSTRACT}

The topic of river pollution is a learning topic that requires Higher Order Thinking Skills (HOTS). Environmental problems also combine with other problems, one of them is corruption cases in environmental issues is also of particular concern, so the need to instill anti-corruption values. The purpose of this study was to develop Students Worksheet based on Anti Corruption and Higher Order Thinking Skills (SWACHOTS) in environmental learning. The research method used is Research and development based on Borg \& Gall (2003). The study was conducted on 12-18 October 2018 in Elementary School 2 of Jatimulya and Junior High School 1 South Tambun, Bekasi. The results showed that the worksheets developed were valid and suitable for environmental learning for Elementary students and Junior High School students with an average score of 3.47. This is because the presentation of SWACHOTS is simple but full of HOTS and anti-corruption values. The conclusion is that developed worksheets are valid and suitable for use in environmental learning.

Keyword: Anti-corruption, HOTS, student worksheets. 
Vol. 04, No. 01 : Hal. $1-8$

Februari 2019

PENDAHULUAN

Lingkungan sekarang ini semakin menunjukan kerusakan, khususnya untuk lingkungan sungai. Banyak lingkungan yang mengalami pencemaran di kota besar yang disebabkan oleh berbagai polutan (Chander \& Muthukrishnan, 2015; Nwankwoala, 2015; Seebauer, Fleiß, \& Schweighart, 2017). Selain rumitnya masalah lingkungan, peran masyarakat juga masih minim dalam menjaga lingkungan tempattinggalnya. Siswa adalah komponen masyarakat yang dapat berkontribusi mengatasi masalah lingkungan. Jenjang Sekolah Dasar (SD) dan Sekolah Menengah Pertama (SMP) merupakan jenjang pendidikan yang sangat penting untuk menanamkan konsep-konsep lingkungan, dikarenakan pada tahapan ini selain menerima berbagai pengetahuan, siswa juga sedang membangun karakternya (Smith, 2014; Sukiniarti, 2016; Vidergor, 2018).

Masalah lingkungan sebenarnya sangatlah kompleks. Siswa yang memiliki perilaku yang baik dalam menjaga lingkungan yang dapat berkontribusi masalah lingkungan, selain itu mereka haruslah memiliki Higher Order Thinking Skills (HOTS) yang tinggi dikarenakan kompleksnya masalah tersebut (Gündüz, Alemdağ, Yaşar, \& Erdem, 2016; Lee, 2014; Saido, Siraj, Nordin, \& Amedy, 2015). Higher Order Thinking Skills terdiri atas 3 aspek, yaitu menganalisis/analyze, mengevaluasi/evaluate dan mencipta/create (Anderson et al., 2001). Kemampuan HOTS tersebut dapat dikembangkan melalui berbagai cara, salah satunya melalui pengembangan Lembar Kerja Siswa (LKS) yang dapat dilakukan untuk berbagai materi dalam hal ini materi lingkungan.

Permasalahan lingkungan selain diperlukan HOTS juga memerlukan pemahaman mengenai nilai-nilai anti
P-ISSN: 2528-679X

E-ISSN: 2597-9833

korupsi. Korupsi merupakan sebuah tindakan untuk memperkaya diri sendiri dengan cara yang tidak sesuai aturan yang berlaku (Almaganbetov, Kenzhibekova, Khvedelidze, Buranbayeva, \& Sailibayeva, 2016; Denisova-Schmidt, Huber, \& Prytula, 2015; Seregig, Suryanto, Hartono, Rivai, \& Prasetyawati, 2018).

Hal ini dikarenakan banyak masalah rusaknya lingkungan disebabkan oleh ulah oknum yang tidak bertanggung jawab, yang di dalam prakteknya seringkali memiliki indikasi ada korupsi. Hal itu membuat siswa juga memerlukan nilai-nilai anti korupsi, hal ini dikarenakan pendidikan anti korupsi dapat dimulai sejak dini untuk tingkat Sekolah Dasar dan Sekolah Menengah Pertama (Almaganbetov et al., 2016; Indawati, 2015). Berkaitan dengan masalah lingkungan diperlukan nilai anti korupsi yang tertanam dalam diri siswa, dikarenakan adanya celah dalam melakukan praktekkorupsi dipermasalahan lingkungan ini. Salah satu hal yang dapat dikembangkan dalam mencegah perbuatan korupsi sejak dini, yaitu menanamkan nilainilai anti korupsi tersebut kepada siswa melalui Lembar Kerja Siswa.

Lembar Kerja Siswa (LKS) merupakan sebuah perangkat pembelajaran yang dapat dikembangkan sendiri oleh guru. Hal ini membuat guru dapat memasukan berbagai konten yang diinginkan ke dalam LKS. Guru dapat mengembangkan LKS sesuai kebutuhan yang diperlukan dalam pembelajaran di sekolah, sehingga isi LKS dapat sangat membantu dalam meningkatkan berbagai kemampuan siswa (Atasoy \& Ergin, 2017; Lee, 2014).

Berdasarkan permasalahan tersebut, maka dilakukan penelitian ini. Tujuan dari penelitian ini untuk mengembangkan Lembar Kerja Siswa (LKS) berbasis nilai 
Vol. 04, No. 01 : Hal. $1-8$

Februari 2019

P-ISSN: 2528-679X

E-ISSN: 2597-9833

anti korupsi dan HOTS untuk siswa atau disebut dengan istilah Students Worksheet based on Anti Corruption and Higher Order Thinking Skills (SWACHOTS). Lembar Kerja Siswa ini menjadi urgen untuk dikembangkan karena minimnya perangkat pembelajaran yang memiliki konten untuk menanamkan karakter siswa. Adapun kebaruan (novelty) yang dihasilkan dalam penelitian ini, yaitu dengan dikembangkannya sebuah LKS yang mengandung nilai-nilai anti korupsi, dengan harapan dapat menumbuhkan karakter siswa yang memiliki sikap jujur dan anti korupsi.

\section{METODE PENELITIAN}

Penelitian ini dilaksanakan pada tanggal 12-18 Oktober 2018 bertempat di SD Negeri Jatimulya 02 dan SMPN 1 Tambun Selatan, Kecamatan Tambun Selatan, Bekasi, Jawa Barat. Metode yang digunakan, yaitu metode penelitian dan

pengembangan menurutBorg and Gall (2003) dengan sedikit penyesuaian. Pada penelitian ini hanya sampai tahap pengembangan saja tidak dilakukan ujicoba SWACHOTS.

Pada tahap awal, dilakukan analisis masalah. Kemudian merancang dan mengembangkan produk, kemudian dilakukan penilaian produk (validasi) oleh berbagai ahli. Tahapan itu merupakan penjabaran dari tahapan pengembangan produk (Borg\& Gall, 2003). Validasi dilakukan dengan melibatkan lima orang ahli yang merupakan user dari SWACHOTS tersebut,yaitu guru yang memahami bidang studi Ilmu Pengetahuan Alam/Biologi. Instrumen validasi SWACHOTS terdiri dari 12 butir. Hasil validasi kemudian dikategorikan ke dalam kategori berikut ini sesuai yang diutarakan oleh Ratumanan \& Laurens (2006)yang dapat dilihat pada Tabel 1.

Tabel 1. Kriteria validasi LKS

\begin{tabular}{cc}
\hline Interval Kategori & Kriteria \\
\hline $3,25<\mathrm{x} \leq 4,00$ & Sangat Valid \\
$2,50 \leq \mathrm{x} \leq 3,25$ & Valid \\
$1,75<\mathrm{x}<2,50$ & Kurang Valid \\
$1,00<\mathrm{x}<1,75$ & Tidak Valid \\
\hline
\end{tabular}

Sumber: Ratumanan \&Laurens (2006)

\section{HASIL DAN PEMBAHASAN}

Setelah dilakukan pengembangan produk, maka dilakukan validasi. Produk SWACHOTS yang berhasil dikembangkan dapat dilihat pada Gambar 1.Hasil validasi menunjukan bahwa SWACHOTS tersebut valid dan sangat valid sehingga layak digunakan. Hal ini terlihat dari penilaian expert yang memberikan penilaian. Lebih jelasnya dapat dilihat pada Tabel 2 .

Tabel 2. Skor Hasil Validasi Produk SWACHOTS

\begin{tabular}{ccccc}
\hline No & Expert & Skor & Rata-rata & Kategori \\
\hline 1 & User 1 & 3.00 & & \\
2 & User 2 & 3.91 & 3.47 & Sangat Valid \\
3 & User 3 & 3.40 & & \\
4 & User 4 & 3.25 & & \\
5 & User 5 & 3.83 & & \\
\hline
\end{tabular}


Vol. 04, No. 01 : Hal. $1-8$

Februari 2019

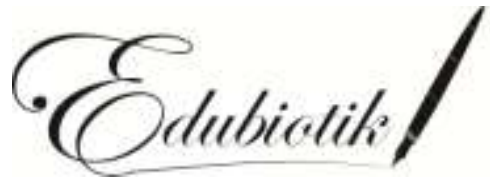

P-ISSN: 2528-679X

E-ISSN: 2597-9833

Berdasarkan Tabel 2menunjukkan bahwa SWACHOTS yang merupakan hasil pengembangan tersebut layak digunakan dalam pembelajaran.Students Worksheet based on Anti Corruption and Higher Order Thinking Skills yang dikembangkan tersebut memiliki banyak fitur yang belum tersedia di berbagai LKS yang ada di pasaran.Hal yang ingin ditekankan dalam SWACHOTS ini, yaitu konten dimana sebuah cerita yang mengandung masalah

lingkungan, kemudian siswa diminta menganalisisnya beradasarkan nilai anti korupsi. Selain menganalisis, siswa juga diminta untuk memberikan kritik dan membuat sebuah karya yang berkaitan dengan cerita tersebut. Hal ini perlu ditanamkan sejak dini, untuk membangun HOTS (Azrai, Ernawati, \& Sulistianingrum, 2017; Bojey, Hui, \& Campbell, 2014; Narayanan \& Adithan, 2015; Zohar \& Alboher Agmon, 2018).

\section{PRODUK \\ Lembar Kerja SiswaBerbasis Nilai Anti Korupsi dan HOTS \\ Students Worksheet based on Anti Corruption and Higher Order Thinking Skills (SWACHOTS)}

LKS dikembangkan oleh Ichsan, Iriani, Hermawati, Dewi

\section{Tujuan Pembelajaran}

Siswa mampu menganalisis, memberikan penilaian, dan menciptakan sebuah produk tentang sebuah masalah pencemaran air yang berkaitan dengan nilai anti korupsi

\section{Petunjuk kegiatan}

1. Bacalah teks di bawah ini

Sebuah sungai di desa X mengalami pencemaran secara tiba-tiba ditandai dengan perubahan warna menjadi hitam pekat.Padahal, kemarin air di sungai tersebut belum mengalami perubahan warna.Para warga pun berdatangan, kemudian Bapak ketua RW (Rukun Warga) selaku tokoh masyarakat menanyakan kepada warga mengenai saksi di tempat kejadian tersebut.Beberapa warga mengaku, melihat sebuah pipa yang berasal dari sebuah pabrik mengalirkan limbah menuju sungai tersebut pada malam hari.

Keesokan harinya datang salah seorang berpakaian rapi dengan jas ke rumah Bapak ketua RW.Pria tersebut datang dikawal beberapa asistennya.Pak RW pun membukakan pintu, kemudian mempersilahkan pria tersebut masuk ke rumah. Kemudian, pria tersebut menawarkan sejumlah uang sebanyak 100 juta rupiah untuk pak RW, dengan tujuan supaya pak RW tidak melaporkan kasus pencemaran sungai yang dilakukan oleh pabrik di desa X tersebut. Pak RW dengan sembunyi-sembunyi ternyata menerima uang tersebut dan tidak melaporkan kasus tersebut ke pihak berwajib.

2. Buatlah kelompok beranggotakan 3 orang, kemudian diskusikan dengan kelompokmu

3. Diskusikan pertanyaan dan lakukan kegiatan berikut ini dengan kelompokmu:

I) Bagaimana pendapatmu mengenai peristiwa pada teks tersebut?

II)Buatlah sebuah analisis, mengapa pria tersebut mendatangi pak RW dan menawarkan uang, dan analisislah dampak pembuangan limbah tersebut bagi kehidupan!

III) Nilai antikorupsi apa yang bisa kamu dapat dari teks tersebut?

IV) Berikan kritik mengenai pabrik pada cerita di atas yang melakukan pembuangan limbah ke sungai!

V)Buatlah sebuah poster yang berisi ajakan untuk menghentikan pembuangan limbah di sungai!

VI) Berikan penilaian, mengenai perilaku pak RW yang menerima uang tersebut! Jika kamu menjadi pak RW, apakah kamu akan menerima uang suap (uang sogokan) juga jika menghadapi peristiwa seperti itu? Jelaskan!

Gambar 1. Produk SWACHOTS yang Berhasil Dikembangkan

(Sumber: Dokumen Pribadi, 2018)

Kemampuan siswa menganalisis masalah kemudian mengkaitkannya dengan

nilai moral anti korupsi yang terdapat dalam SWACHOTS tersebut merupakan 
Vol. 04, No. 01 : Hal. $1-8$

Februari 2019

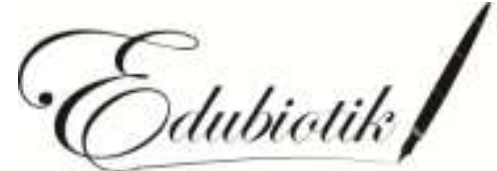

P-ISSN: 2528-679X

E-ISSN: 2597-9833

pengaplikasian dari ranah $\mathrm{C} 4$ (analyze). Kemampuan siswa dalam menganalisis dapat ditingkatkan dengan cara memberikan sebuah permasalahan yang dekat dengan kehidupan sehari-hari siswa tersebut. Persoalan pencemaran yang disajikan dalam SWACHOTS ini dikarenakan masalah tersebut sangat dekat dengan lingkungan siswa tinggal. Masalah-masalah tersebut sering mereka temui, sehingga mereka lebih mudah melakukan analisis terhadap permasalahan tersebut (Ramdhani \& Muhammadiyah, 2015; Taft, 2015; Vijayaratnam, 2012).

Nilai anti korupsi yang diangkat dalam LKS ini juga lebih spesifik kepada masalah kejujuran. Hal ini berkaitan dengan proses pembelajaran di kelas yang juga sangat mengedepankan kejujuran. Siswa diminta untuk memberikan kritik terhadap sikap seorang tokoh masyarakat yang menerima suap dari oknum yang melakukan pembuangan limbah.Siswa diminta untuk memberikan penilaian (evaluate) terhadap perilaku dan sikap para tokoh yang melakukan dan menerima suap tersebut yang berada di dalam cerita. Tentu, perilaku dengan cara menyuap seperti itu sangatlah buruk, begitu juga yang menerima suap. Perintah untuk memberikan penilaian merupakan penerapan aspek C5 (evaluate). Tugas seperti ini akan memicu siswa untuk dapat membedakan, menilai, dan mengkritisi permasalahan tersebut (Ennis, 2018; Koh, Chai, Wong, \& Hong, 2015; Santos, 2017; Sigit, Ernawati, \& Qibtiah, 2017; Suryanda, Azrai, \& Wari, 2016).

Kemampuan mencipta(create) siswa yang diangkat dalam SWACHOTS ini, yaitu siswa diminta untuk membuat sebuah poster yang berkaitan dengan masalah lingkungan. Hal ini tentu merupakan sebuah kemampuan yang berkaitan dengan aspek
C6 (create), yaitu mencipta. Siswa diminta berkreasi dengan cara membuat sebuah poster yang berisi himbauan untuk tidak melakukan perbuatan yang merusak lingkungan. Tugas seperti ini dapat memicu siswa untuk mengeluarkan kemampuannya dalam membuat sesuatu. Siswa diminta membuat sebuah proyek, hal ini akan membantu meningkatkan kreatifitasnya dalam pembelajaran (Husamah, Fatmawati, \& Setyawan, 2018; Kivunja, 2014; Şener, Türk, \& Taş, 2015).

Nilai-nilai anti korupsi sendiri dapat ditanamkan sejak dini. Penanaman ini dimulai sejak siswa di sekolah dasar dan sekolah menengah pertama. Siswa yang memiliki dan memahami nilai-nilai anti korupsi diharapkan dapat berperan aktif untuk mencegah perbuatan korupsi di masa yang akan datang. Pendidikan anti korupsi bisa dimulai sejak dini dengan cara membiasakan melakukan sesuatu dengan jujur. Memang untuk membiasakan siswa untuk berlaku jujur merupakan hal yang tidak mudah, namun bisa mulai dibiasakan sejak SD dan SMP. Guru dapat menyisipkan nilai anti korupsi tersebut di dalam berbagai mata pelajaran. Guru dapat melakukan pengembangan sendiri terhadap perangkat pembelajarannya (Sadiqin, Sholahuddin, \& Santoso, 2017; Ugulu, Sahin, \& Baslar, 2013). Selain itu dikarenakan sebenarnya nilai anti korupsi ini bersifat umum, bukan merupakan konsep yang dimiliki oleh suatu bidang ilmu tertentu. Mata pelajaran Ilmu Pengetahuan Alam merupakan salah satu yang dapat disisipkan konsep anti korupsi karena pada dasarnya mata pelajaran IPA mengedepankan daya pikir yang kritis (Istiana \& Awaludin, 2018; Sadiqin et al., 2017; Smith, 2014; Uzun, 2012) 
Vol. 04, No. 01 : Hal. $1-8$

Februari 2019

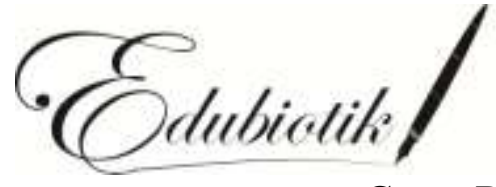

P-ISSN: 2528-679X

E-ISSN: 2597-9833

\section{SIMPULAN DAN SARAN}

Berdasarkan hasil penelitian dapat disimpulkan bahwa LKS yang berbasis HOTS dan nilai anti korupsi (SWACHOTS) layak digunakan dalam pembelajaran bagi siswa SD dan SMP.Hal ini dapat dimungkinkan mengingat mata pelajaran Ilmu Pengetahuan Alam (IPA) sangat mengedepankan daya kritis siswa. Masalah yang diangkat berupa permasalahan lingkungan yang sangat dekat dengan kehidupan sehari-hari membuat siswa mudah melakukan analisis, penilaian, dan menciptakan sebuah produk yang merupakan pengaplikasisan dari HOTS. Diperlukan adanya uji keefektifan Lembar Kerja Siswa (LKS) terhadap keterampilan berpikir tingkat tinggi.

\section{RUJUKAN}

Almaganbetov, P., Kenzhibekova, E., Khvedelidze, T., Buranbayeva, S., \& Sailibayeva, Z. (2016). Foreign Experience of Formation of AntiCorruption Strategies. International Journal of Environmental \& Science Education, 11(15), 8507-8516. https://doi.org/10.1016/S01665162(96)00034-1

Anderson, L. W., Krathwohl, D. R., Airiasian, W., Cruikshank, K. A., Mayer, R. E., \& Pintrich, P. R. (2001). A taxonomy for learning, teaching and assessing: A revision of Bloom's Taxonomy of educational outcomes: Complete edition. New York: Longman.

Atasoy, Ş., \& Ergin, S. (2017). The effect of concept cartoon-embedded worksheets on grade 9 students' conceptual understanding of Newton's Laws of Motion. Research in Science and Technological Education, 35(1), 58-73.

https://doi.org/10.1080/02635143.2016. 1248926

Azrai, E. P., Ernawati, E., \& Sulistianingrum, G. (2017). Pengaruh
Gaya Belajar David Kolb (Divergen, Assimilator,

Convergen,

Accommodator) Terhadap Hasil Belajar Siswa Pada Materi Pencemaran Lingkungan. Biosfer: Jurnal Pendidikan Biologi, 10(1), 9-16. https://doi.org/https://doi.org/10.21009/ biosferjpb.10-1.2

Bojey, M., Hui, B., \& Campbell, R. (2014). Engaging higher order thinking skills with a personalized physics tutoring system. Lecture Notes in Computer Science (Including Subseries Lecture Notes in Artificial Intelligence and Lecture Notes in Bioinformatics), 8474 LNCS, 613-614. https://doi.org/10.1007/978-3-31907221-0_78

Chander, P., \& Muthukrishnan, S. (2015). Green consumerism and pollution control. Journal of Economic Behavior and Organization, 114, 27-35. https://doi.org/10.1016/j.jebo.2015.02.0 13

Denisova-Schmidt, E., Huber, M., \& Prytula, Y. (2015). An experimental evaluation of an anti-corruption intervention among Ukrainian university students. Eurasian Geography and Economics, 56(6), 713-734.

https://doi.org/10.1080/15387216.2016. 1155467

Ennis, R. H. (2018). Critical Thinking Across the Curriculum: A Vision. Topoi, 37(1), 165-184. https://doi.org/10.1007/s11245-0169401-4

Gall, M. D., Gall, J. P., \& Borg, W. R. (2003). Educational Research An Introduction. San Fransisco: Pearson Education.

Gündüz, A. Y., Alemdağ, E., Yaşar, S., \&Erdem, M. (2016). Design of a Problem-Based Online Learning Environment and Evaluation of its Effectiveness. The Turkish Online Journal of Educational Technology, 15(3), 49-57. https://doi.org/10.1017/CBO97811074 15324.004 
Vol. 04, No. 01 : Hal. 1 - 8

Februari 2019

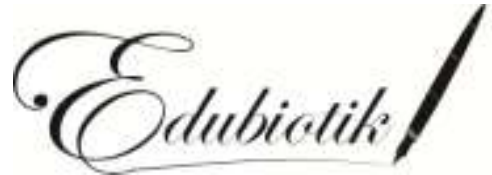

P-ISSN: 2528-679X

E-ISSN: 2597-9833

Husamah, H., Fatmawati, D., \& Setyawan, D. (2018). OIDDE Learning Model: Improving Higher Order Thinking Skills of Biology Teacher Candidates. Interntaional Journal of Instruction, 11(2), 249-264.

Indawati, N. (2015). The Development of Anti-Corruption Education Course for Primary School Teacher Education Students. Journal of Education and Practice, 6(35), 48-54.

Istiana, R., \& Awaludin, M. T. (2018). Enhancing biology education students ability to solve problems in environmental science material through inquiri model-based lesson study. Biosfer: Jurnal Pendidikan Biologi, 11(1), 57-66. https://doi.org/https://doi.org/10.21009/ biosferjpb.11-1.6

Kivunja, C. (2014). Teaching Students to Learn and to Work Well with 21st Century Skills: Unpacking the Career and Life Skills Domain of the New Learning Paradigm. International Journal of Higher Education, 4(1), 111. https://doi.org/10.5430/ijhe.v4n1p1

Koh, J. H. L., Chai, C. S., Wong, B., \& Hong, H. Y. (2015). Design Thinking and 21st Century Skills. In Design Thinking for Education: Conceptions and Applications in Teaching and Learning (pp. 1-131). https://doi.org/10.1007/978-981-287444-3

Lee, S. M. (2014). The relationships between higher order thinking skills, cognitive density, and social presence in online learning. Internet and Higher Education, 21, 41-52. https://doi.org/10.1016/j.iheduc.2013.1 2.002

Narayanan, S., \& Adithan, M. (2015). Analysis of Question Papers in Engineering Courses with Respect to HOTS (Higher Order Thinking Skills). American Journal of Engineering Education, 6(1), 1-10.

Nwankwoala, H. N. L. (2015). Causes of Climate and Environmental Changes: The Need for Environmental-Friendly

Education Policy in Nigeria. Journal of Education and Practice, 6(30), 224234.

Ramdhani, M. A., \& Muhammadiyah, H. (2015). The Criteria of Learning Media Selection for Character Education in Higher Education. International Conference of Islamic Educatios in Shoutheast Asia, (March), 1-9.

Ratumanan, T. ., \& Laurens, T. (2006). Evaluasi Hasil Belajar yang Relevan dengan Kurikulum Berbasis Kompetensi. Surabaya: Unesa University Press.

Sadiqin, I. K., Sholahuddin, A., \& Santoso, U. T. (2017). Students' Difficulties on Science Learning with Prototype Problem-Solving Based Teaching and Learning Material : A Study Evaluation of Development Research. Advances in Social Science, Education and Humanities Research, 100, 279-282.

Saido, G. M., Siraj, S., Nordin, A. B. Bin, \& Amedy, O. S. A. (2015). Higher Order Thinking Skills Among Secondary School Students in Science Learning. The Malaysian Online Journal of Educational Science, 3(3), 13-20.

Santos, L. F. (2017). The Role of Critical Thinking in Science Education. Journal of Education and Practice, 8(20), 158-173.

Seebauer, S., Fleiß, J., \& Schweighart, M. (2017). A Household Is Not a Person: Consistency of Pro-Environmental Behavior in Adult Couples and the Accuracy of Proxy-Reports. Environment and Behavior, 49(6), 603-637.

https://doi.org/10.1177/0013916516663 796

Şener, N., Türk, C., \& Taş, E. (2015). Improving Science Attitude and Creative Thinking through Science Education Project: A Design, Implementation and Assessment. Journal of Education and Training Studies, 3(4), 57-67. https://doi.org/10.11114/jets.v3i4.771

Seregig, I. K., Suryanto, T., Hartono, B., 
Vol. 04, No. 01 : Hal. $1-8$

Februari 2019

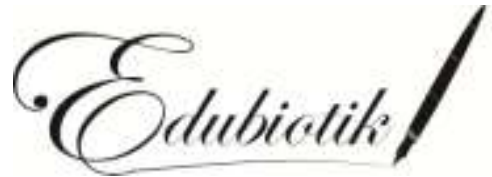

P-ISSN: 2528-679X

E-ISSN: 2597-9833

Rivai, E., \& Prasetyawati, E. (2018). Preventing the Acts of Corruption through Legal Community Education. Journal of Social Studies Education Research, 9(2), 138-159.

Sigit, D. V., Ernawati, E., \& Qibtiah, M. (2017). Hubungan Pengetahuan Lingkungan Hidup dengan Kemampuan Pemecahan Masalah Pencemaran Lingkungan Pada Siswa Sman 6 Tangerang. Biosfer: Jurnal Pendidikan Biologi, 10(2), 1-6. https://doi.org/https://doi.org/10.21009/ biosferjpb.10-2.1

Smith, T. (2014). Elementary Science Instruction: Examining a Virtual Environment for Evidence of Learning, Engagement, and 21st Century Competencies. Education Sciences, 4(1), 122-138. https://doi.org/10.3390/educsci4010122

Sukiniarti. (2016). Improving Science Pedagogic Quality in Elementary School Using Process Skill Approach Can Motivate Student to Be Active in Learning. Journal of Education and Practice, 7(5), 150-157.

Suryanda, A., Azrai, E. P., \& Wari, N. (2016). Pengaruh Penerapan Model Pembelajaran Group Investigation (GI) Terhadap Kemampuan Berpikir Analisis Siswa Pada Materi Pencemaran Lingkungan. Biosfer: Jurnal Pendidikan Biologi, 9(2), 3744.

https://doi.org/https://doi.org/10.21009/ biosferjpb.9-2.6

Taft, M. M. (2015). Higher - Order Critical Thinking in Teacher Preparation. In Transformative Researchers and Educators for Democracy (pp. 57-73).
Ugulu, I., Sahin, M., \& Baslar, S. (2013). High School Students' Environmental Attitude: Scale Development and Validation. International Journal of Educational Sciences, 5(4), 415-424. https://doi.org/10.1080/09751122.2013. 11890103

Uzun, N. (2012). A Sample of Active Learning Application in Science Education: The Thema "Cell" with Educational Games. Procedia - Social and Behavioral Sciences, 46, 29322936.

https://doi.org/10.1016/j.sbspro.2012.0 5.592

Vidergor, H. E. (2018). Effectiveness of the multidimensional curriculum model in developing higher-order thinking skills in elementary and secondary students. Curriculum Journal, 29(1), 95-115. https://doi.org/10.1080/09585176.2017. 1318771

Vijayaratnam, P. (2012). Developing Higher Order Thinking Skills and Team Commitment via Group Problem Solving: A Bridge to the Real World. Procedia - Social and Behavioral Sciences, 66, 53-63. https://doi.org/10.1016/j.sbspro.2012.1 1.247

Zohar, A., \& Alboher Agmon, V. (2018). Raising test scores vs. teaching higher order thinking (HOT): senior science teachers' views on how several concurrent policies affect classroom practices. Research in Science and Technological Education, 36(2), 243260.

https://doi.org/10.1080/02635143.2017. 1395332 